\title{
Effects of supplementation with combination of polyunsaturated oils in diet of horses in maintenance and during marcha training
}

\section{Efeito da suplementação com combinação de óleos poliinsaturados na dieta de cavalos em manutenção e durante treino de marcha}

Ana Isabela Alves Diniz e Sá1 (D) , Stephânia Katurchi Mendes Melo (D) , Helena Emília Cavalcanti da Costa Cordeiro Manso ${ }^{1}$ (D) , Helio Cordeiro Manso Filho ${ }^{1 *}$ (D)

'Universidade Federal Rural de Pernambuco, Recife, PE, Brazil

*Correspondent - helio.mansofo@ufrpe.br

\begin{abstract}
This study aimed to evaluate the effects of supplementation with polyunsaturated oil on lipid and mineral blood biomarkers in two different groups of horses. Was used 6 healthy horses in maintenance (MT-g) and 10 healthy horses in marcha gait training (GT-g). The MT-g and the GT-g received $100 \mathrm{~mL}$ and $300 \mathrm{~mL} /$ day/animal of combination of polyunsaturated oils, respectively, during 8 weeks. Blood was collected in pretest and after 4 and 8 weeks, after overnight fasting and it was measured: total cholesterol, HDL cholesterol, LDL cholesterol, triglyceride, NEFA, LPS, glycerol, $\mathrm{Ca}, \mathrm{P}, \mathrm{Mg}$, and $\mathrm{Cl}$. The supplementation produced significant increase in NEFA and reduction in lipase in both groups. In addition, the LPS content in both groups had a large decrease $(\sim 35 \%)$ from the pre-test to the 8th week of supplementation. In the MT-g, the LDL cholesterol and glycerol increased significantly after 4 weeks but returned to the pre-test levels after 8 weeks, and the triglyceride content decreased $(\sim 62 \%)$ after 4 weeks. The total cholesterol concentration in the GT-g increased after 4 weeks $(70 \%)$, but after 8 weeks it decreased to levels similar to those observed in the pre-test. The mineral biomarkers increased in the MT-g and GT-g, after 8 weeks. In the MT-g and in the GT-g, Ca decreased. In conclusion, supplementation with a combination of polyunsaturated oils increased NEFA concentration and reduced LPS activity in both groups, unlike the concentrations of the other biomarkers that showed different variations between groups, indicating that both NEFA and LPS the changes in their concentrations during supplementation may be more sensitive and more indicated for these types of evaluation. In addition, some blood mineral concentrations reduced significantly in both groups of horses, and thus, they need to be evaluated in horses under chronic oil supplementation
\end{abstract}

Section: Zootecnia

Received

June 13, 2018

Accepted

August 5, 2019

Published

April 22, 2020

www.revistas.ufg.br/vet visit the website to get the how to cite in the article page.
Keywords: Fat, NEFA, lipase, exercise

\section{Resumo}

O objetivo deste estudo foi avaliar os efeitos da suplementação com uma combinação de óleos poliinsaturado nos biomarcadores lipídicos e minerais sanguíneos em dois diferentes grupos de equinos. Foram utilizados 6 equinos saudáveis em manutenção (MT-g) e 10 equinos saudáveis em 
treinamento de marcha (GT-g). O MT-g e o GT-g receberam 100,0mL e $300 \mathrm{~mL} /$ dia/animal de uma combinação de óleos poliinsaturado, respectivamente, durante 8 semanas. O sangue foi coletado no préteste e após 4 e 8 semanas, após a noite, medidas: colesterol total, colesterol HDL, colesterol LDL, triglicérides, NEFA, LPS, glicerol, Ca, P, $\mathrm{Mg}$ e $\mathrm{Cl}$. A suplementação produziu aumento significativo de NEFA e redução da lipase nos dois grupos. Além disso, o conteúdo de LPS em ambos os grupos ocorreu um decréscimo ( 35\%) desde o pré-teste até a $8^{\mathrm{a}}$ semana de suplementação. Na MT-g, o colesterol LDL e o glicerol aumentaram significativamente após 4 semanas, mas retornaram aos níveis pré-teste após 8 semanas, e o conteúdo de triglicérides diminuiu ( $62 \%)$ após 4 semanas. A concentração total de colesterol no GT-g aumentou após 4 semanas ( 70\%), mas após 8 semanas diminuiu para valores semelhantes aos observados no pré-teste. Os biomarcadores minerais aumentaram no MT-g e GT-g, após 8 semanas. No MT-g e no GT-g, o Ca diminuiu. Em conclusão, a suplementação com uma combinação de óleos poliinsaturado elevou a concentração do NEFA e reduziu a atividade de LPS em ambos os grupos estudados, diferentemente das concentrações das demais biomarcadores que apresentaram variações diferentes entre os grupos, indicando que tanto o NEFA como a LPS podem ser mais sensíveis as modificações em suas concentrações durante a suplementação e mais indicados para esse tipo de avaliação. Além disso, a concentração sanguínea de alguns minerais reduziu significativamente em ambos os grupos de equinos e, portanto, precisam ser avaliados em cavalos sob suplementação crônica de óleos.

Palavras-chaves: lipídeos, NEFA, lipase, exercício

\section{Introduction}

During last decade, many researchers analyzed the effects of fat supplementation in horses under different management and exercise systems, principally because nonesterified fatty acids (NEFA) and other lipids are important as an energetic metabolite to the aerobic exercise ${ }^{(1,2)}$. Fat supplementation produces an increase in different blood lipid biomarkers, like NEFA ant triglycerides ${ }^{(3,4)}$, which supports glycogen sparing and improves antioxidant capacity ${ }^{(2,5,6)}$. Furthermore, other studies have shown that horses were well adapted to a supplementation with one type of fat or a combination of two or more types ${ }^{(1,2,6)}$, contributing with new products' development for equine industry.

Because these finds, researchers now are investigating supplementations with different types of fat and/or fat combination in order to understand the effects of this nutritional program in horses. It was shown that chronic fat supplementation, with saturated or unsaturated vegetable oils produced an equivalent increase in NEFA and vitamin E concentration ${ }^{(1,3)}$, because both type of oil follow similar pathway during their metabolism in horses. In another study, researchers compared the supplementation with soybean against the palm oil, and did not find a positive effect on triglyceride and NEFA in both products(10). In contrast, supplementation with fish or corn oil, it was showed that fish oil decreases triglyceride concentration and changes the fatty acid 
profile in athletic horses and ponies ${ }^{(3,11)}$, improving the antioxidant capacity in these animals. Some of these difference in the results have association with oils composition, where proportion of omega 3, 6 and 9 contribute to oils digestibility and synthesis of different biomarkers.

Fat supplementation has demonstrated to be important for different groups of horses, but because there is a large spectrum of oil/fat combination, it was developed a study to investigate the effects of supplementation with a rich polyunsaturated oil and vitamin E on lipid and mineral blood biomarkers in horses in maintenance and in marcha gait training. Our hypothesis was that such supplementation with this mixture of oils would not promote similar adaptation in some blood lipid and mineral biomarkers in both groups, despite of different levels of energy expenditure.

\section{Material and methods}

It was used 6 healthy mares in maintenance $(14.0 \pm 2.5$ years old; $350 \pm 20 \mathrm{~kg})$, and 10 healthy equines in marcha training program ( 6 horses and 4 mares; $7.0 \pm 2.0$ years old; $360 \pm 15 \mathrm{~kg}$ ). The maintenance group (MT-g) spend 24 hours outside in dry-lots and the marcha gait training (GT-g) had training sections during 50 minutes, 3 days a week, where $40 \%$ walking and $60 \%$ gaiting at $\sim 4.0 \mathrm{~m} / \mathrm{s}$. In addition, all animals had negative test for Equine Infectious Anemia and Glanders, and were under regular sanitary program, with vaccines, deworming procedures and ectoparasites controls.

The horses in maintenance (MT-g) were kept at a collective dry-lot ( $\sim$ hectares) and they received commercial pellets (Equimax 12MA, Irca Nutrição Animal, Carpina-PE, Brazil) (3.0 kg/day/animal) and Tifton hay (Cynodon spp; 5,0 kg DM/day/animal), and they also received $100.0 \mathrm{~mL} /$ day/animal of a mixture of polyunsaturated oil and vitamin E (MegaEnegy, Integralmix Nutrição Animal, Fortaleza-CE, Brazil) (Table 1) per os, at the morning meal during 8 weeks.

In contrast, the horses in marcha gait training (GT-g), were kept in a individual small dry-lot ( 1 hectare), and they received commercial pellets (Equinos Durancho 12MA, DuRancho Nutrição Animal, Pesqueira-PE, Brasil) $(5.0 \mathrm{~kg} /$ day/animal; Table 3) with chopped fresh Elephant grass (Pennisetum purpureum; $\sim 5,0 \mathrm{~kg} \mathrm{DM} /$ day/animal, divided 3 times per day). The GT-g was supplemented with $300.0 \mathrm{~mL} /$ day/animal of a mixture of polyunsaturated oil and vitamin E2 (Table 1) per os, divided into two meals (150 mL, 6 AM and $150 \mathrm{~mL}, 5 \mathrm{PM}$ ) for 8 weeks, without pre-test adaptation period. Finally, both groups had their nutritional program adjusted to receive the NRC (2007) recommendation for their categories. Both groups had free access to fresh water and mineral salt.

Blood samples were collected in both groups at the pre-test and after 4 and 8 weeks, after overnight fasting, using pre-chilled vacuum tubes with heparin. All samples were immediately refrigerated and in less than 1 hour they were centrifuged to extract plasma, which was stored at $-80^{\circ} \mathrm{C}$ until analysis. These samples were used to measure biomarkers of lipid metabolism (total cholesterol, HDL cholesterol, LDL cholesterol, triglyceride), and biomarkers of mineral metabolism (calcium, phosphorus, magnesium, 
and chlorides) in a semi-automated biochemistry analyzer (D-250 espectrofotometro, Doles ${ }^{\circledR}$, São Paulo-SP, Brazil.) with commercial kits (Doles Reagentes, Goiania-GO, Brazil). Lipase (LPS) and non-esterified fatty acids (NEFA) were measured using a commercial kit (Randox ${ }^{\circledR}$ Laboratórios, São Paulo-SP, Brasil), and the glycerol analysis was made using ELISA plate reader (Mindray MR-96A ELISA microplate reader, Mindray Medical International Limited, São Paulo-SP, Brazil) using commercial kits (Glicerol reagentes, Bioensaio Sistemas, São Paulo-SP, Brazil). All samples were analyzed in duplicate.

Table 1. Composition of the combination of polyunsaturated oils used in maintenance and marcha gait training horses during experimental periods, according to the manufacturer

\begin{tabular}{lc}
\hline Analysis & Quantity \\
\hline Humidity (max) & $10.0 \mathrm{~g}$ \\
Digestible energy (min) & $8.5 \mathrm{Mcal}$ \\
Fat (min) & $980.0 \mathrm{~g}$ \\
Omega 3 (min) & $300.0 \mathrm{~g}$ \\
Omega 6 (min) & $80.0 \mathrm{~g}$ \\
Free acidy in Oleic acid (max) & $20.0 \mathrm{~g}$ \\
Vitamin E (min) & $300.0 \mathrm{Ul}$ \\
Peroxide index (max) & $20.0 \mathrm{~m} \mathrm{Eq}$ \\
\hline
\end{tabular}

Observations: results expressed per liter of the product; max: maximum; min: minimum

The data from each group were submitted to one-way ANOVA for repeated measurements, and post hoc Tukey test, using SigmaPlot 13.0 (SigmaPlot 13.0 para Windows, Systat Software Ind. San Rafael-CA, USA). All analyses were performed at 5\% significance level and results were expressed in mean \pm standard error of the mean (SEM).

\section{Results}

The results of the lipid biomarker showed that supplementation with polyunsaturated oil and vitamin E produced significant increase in non-esterified fatty acids (NEFA) and reduction of the lipase (LPS) concentrations in both groups (Table 2). In the maintenance group (MT-g), the NEFA content was low in the pre-test $(\sim 38 \mathrm{mmol} / \mathrm{mL})$ and had large increase after 4 weeks $(\sim 1,240 \%)$ and after 8 weeks $(\sim 620 \%)(P<0.05)$. In the gait training group (GT-g), the NEFA concentration increased in a similar way after 4 and 8 weeks $(\sim 540 \%)$ and it was different from the value observed in the pre-test $(\sim 48 \mathrm{mmol} / \mathrm{mL})$ $(P<0.05)$. In addition, the LPS concentration in both groups had a large decrease $(\sim 35 \%)$ from the pre-test to the 8th week of supplementation.

Some lipid biomarkers had significant changes only in one group (Table 2). In the MT-g, the LDL cholesterol and glycerol concentrations increased significantly after 4 weeks 
but returned to pre-test levels after 8 weeks, and the triglycerides decreased ( 62\%) after 4 weeks and kept this reduced concentration after 8 weeks $(P<0.05)$. The total cholesterol concentration in the GT-g increased after 4 weeks $(\sim 70 \%)(P<0.05)$, but after 8 weeks it decreased to levels similar to those observed in the pre-test $(P>0.05)$.

Table 2. Biomarkers of lipid metabolism in maintenance and marcha gait training horses, after supplementation with polyunsaturated oils, during 8 weeks

\begin{tabular}{|c|c|c|c|}
\hline \multirow[t]{2}{*}{ Biomarkers } & \multicolumn{3}{|c|}{ Experimental periods } \\
\hline & Pre-test & +4 weeks & +8 weeks \\
\hline \multicolumn{4}{|l|}{ Maintenance $(n=6)$} \\
\hline Total cholesterol (mg/dL) & $67.17 \pm 3.90$ & $75.22 \pm 10.05$ & $60.48 \pm 10.58$ \\
\hline LDL cholesterol (mg/dL) & $25.17 \pm 6.31^{\mathbf{B}}$ & $49.00 \pm 5.65^{A}$ & $22.03 \pm 3.00^{\mathbf{B}}$ \\
\hline HDL cholesterol (mg/dL) & $156.04 \pm 69.33$ & $104.81 \pm 32.75$ & $300.08 \pm 105.22$ \\
\hline Triglycerides (mg/dL) & $99.35 \pm 3.68^{A}$ & $62.63 \pm 4.04^{\mathrm{B}}$ & $51.61 \pm 4.30^{\mathbf{B}}$ \\
\hline $\mathrm{NEFA}(\mathrm{mmol} / \mathrm{mL})$ & $38.20 \pm 7.84^{c}$ & $472.00 \pm 71.50^{A}$ & $235.00 \pm 54.70^{\mathrm{B}}$ \\
\hline Lipase (U/L) & $196.34 \pm 11.20^{A}$ & $137.57 \pm 13.13^{\mathbf{B}}$ & $130.02 \pm 22.26^{\mathrm{B}}$ \\
\hline Glycerol (mg/L) & $41.2 \pm 6.4^{\mathrm{B}}$ & $83.7 \pm 8.8^{\mathrm{A}}$ & $67.0 \pm 6.7^{\mathrm{AB}}$ \\
\hline \multicolumn{4}{|c|}{ Marcha gait training $(n=10)$} \\
\hline Total cholesterol (mg/dL) & $41.50 \pm 2.79^{B}$ & $69.85 \pm 7.23^{A}$ & $63.16 \pm 8.08^{A B}$ \\
\hline LDL cholesterol (mg/dL) & $25.32 \pm 4.33$ & $34.42 \pm 4.11$ & $35.74 \pm 5.44$ \\
\hline HDL cholesterol (mg/dL) & $103.87 \pm 17.80$ & $100.09 \pm 21.36$ & $138.40 \pm 30.16$ \\
\hline Triglycerides (mg/dL) & $53.79 \pm 2.86$ & $54.54 \pm 3.27$ & $49.57 \pm 1.99$ \\
\hline $\mathrm{NEFA}(\mathrm{mmol} / \mathrm{mL})$ & $48.20 \pm 7.25^{\mathrm{B}}$ & $261.00 \pm 61.70^{A}$ & $274.00 \pm 76.40^{A}$ \\
\hline Lipase (U/L) & $240.74 \pm 25.90^{A}$ & $189.97 \pm 15.87^{\text {АВ }}$ & $163.93 \pm 17.39^{\mathrm{B}}$ \\
\hline Glycerol (mg/L) & $30.6 \pm 4.0$ & $43.4 \pm 4.8$ & $43.8 \pm 5.0$ \\
\hline
\end{tabular}

Observation: different letters in the same line indicate significant difference $(P<0.05)$ by Tukey's test.

Analyzing the mineral biomarkers, it was possible to observe a small increase in chlorides concentration in the MT-g and GT-g $(\mathrm{P}<0.05)$ after 8 weeks of supplementation (Table 3). In the MT-g, it was also observed a small decreased in P concentration ( 6\%), and in the GT-g, there was a small decrease in Ca concentration ( $5 \%)$. The results of the concentrate's analysis, used in both groups, are shown in Table 4. Finally, there was no problem regarding the intake of the concentrates with oil, and during the supplementation period, the experimental animals had no health problem associated with oil supplementation. 
Table 3. Biomarkers of mineral metabolism in maintenance and marcha gait training horses, after supplementation with polyunsaturated oil, during 8 weeks

\begin{tabular}{|c|c|c|c|}
\hline \multirow{2}{*}{ Biomarkers } & \multicolumn{3}{|c|}{ Experimental periods } \\
\hline & Pre-test & +4 weeks & +8 weeks \\
\hline \multicolumn{4}{|c|}{ Maintenance group $(n=6)$} \\
\hline Calcium, mg/dL & $10.17 \pm 0.05$ & $10.013 \pm 0.11$ & $9.93 \pm 0.14$ \\
\hline Phosphorus, mg/dL & $4.65 \pm 0.05^{\mathrm{A}}$ & $4.42 \pm 0.04^{B}$ & $4.37 \pm 0.07^{B}$ \\
\hline Magnesium, mg/dL & $1.14 \pm 0.01$ & $1.14 \pm 0.001$ & $1.13 \pm 0.004$ \\
\hline Chlorides, mg/dL & $98.17 \pm 1.19^{A B}$ & $94.72 \pm 1.02^{\mathbf{B}}$ & $102.80 \pm 1.28^{\mathrm{A}}$ \\
\hline \multicolumn{4}{|l|}{$\begin{array}{l}\text { Marcha gait } \\
\text { training(n=10) }\end{array}$} \\
\hline Calcium, mg/dL & $10.36 \pm 0.07^{A}$ & $10.31 \pm 0.17^{A}$ & $9.80 \pm 0.06^{B}$ \\
\hline Phosphorus, mg/dL & $4.64 \pm 0.08$ & $4.52 \pm 0.06$ & $4.57 \pm 0.07$ \\
\hline Magnesium, mg/dL & $1.14 \pm 0.006$ & $1.15 \pm 0.01$ & $1.13 \pm 0.006$ \\
\hline Chlorides, mg/dL & $97.45 \pm 1.02^{\mathrm{B}}$ & $97.63 \pm 0.64^{B}$ & $107.08 \pm 0.70^{A}$ \\
\hline
\end{tabular}

Observation: different letters in the same line indicate significant difference $(P<0.05)$ by Tukey's test.

Table 4. Results of the chemical analysis of the commercial pellet used in maintenance and gait training horses during the experimental periods

\begin{tabular}{|c|c|c|}
\hline \multirow[b]{2}{*}{ Analysis } & \multicolumn{2}{|c|}{ Commercial pellet } \\
\hline & Maintenance $^{1}$ & $\begin{array}{c}\text { Marcha gait } \\
\text { exercise }^{2}\end{array}$ \\
\hline Dry mater (\%) & 88.39 & 87.66 \\
\hline Protein (\%) & 16.24 & 16.22 \\
\hline Fat $(\%)$ & 1.13 & 3.37 \\
\hline Fiber in neutral detergent (\%) & 50.32 & 31.56 \\
\hline Fiber in acid detergent (\%) & 21.94 & 10.24 \\
\hline Energy (Mcal/g) & 3.64 & 4.01 \\
\hline
\end{tabular}

Observation: results expressed in percentage of the dry matter; 1-Equimax 12MA, Irca Nutrição Animal, Carpina-PE, Brasil, 2- Equinos Durancho 12MA, DuRancho Nutrição Animal, Pesqueira-PE, Brasil.

In this research, the supplementation with a commercial product rich in polyunsaturated oil and vitamin E produced significant changes in the NEFA concentration ([NEFA]) in both groups, maintenance and marcha gait training, which was not expected 
because there are large difference in animal's energy expenditure. We were expected that marcha horses may have some increase in these lipid biomarkers but final concentration could be below from the maintenance concentration. The [NEFA] was low in the pre-test in both groups (MT-g: $\sim 38 \mathrm{mmol} / \mathrm{mL} ; \mathrm{GT}-\mathrm{g}: \sim 48 \mathrm{mmol} / \mathrm{mL}$ ), which is frequently in horses that received concentrate rich in carbohydrates and poor in $\mathrm{fat}^{(4)}$. However, in another research with ponies, NEFA concentration was between $90-110 \mathrm{mmol} / \mathrm{mL}$ in ponies that received large amount of carbohydrate and higher in another group that was supplemented with fat $(130-160 \mathrm{mmol} / \mathrm{mL})^{(3)}$, confirming that animals under supplementation with fat, likely to have elevated [NEFA]. However, [NEFA] is not well established in horses and ponies, because there are many types of management and exercise programs, contributing to these differences.

Different researchers found that [NEFA] in horses ranges from 70 to $400 \mathrm{mmol} /$ $\mathrm{mL}^{(1,3,4,10,11,14,15)}$, with low values normally detected after overnight fasting in horses and ponies that were not supplemented with fat. Orme et al.(9) showed values of NEFA around $600 \mathrm{mmol} / \mathrm{mL}$ in horses with no oil supplementation, and Watson et al. ${ }^{(16)}$ showed [NEFA] in obese and healthy ponies around $1,670 \mathrm{mmol} / \mathrm{mL}$ and $400 \mathrm{mmol} /$ $\mathrm{mL}$, respectively. In horses with colic, [NEFA] was $\sim 830 \mathrm{mmol} / \mathrm{L}^{(14)}$, showing that some groups of horses had very high [NEFA] under physiological or pathological conditions. Comparing the results of the present study and the range described above, it was detected that for the [NEFA] at in the MT-g and GT-g in pre-test were lower than those described by different researchers, but the concentrations observed in the experimental groups, after 4 and 8 weeks, were inside the range described early. Due to this large variation in NEFA concentration between researches, it is important to evaluate the type of concentrate and forage, the methodology of blood collection and the level of exercise of all researches to understand this important lipid biomarker.

At the literature, [NEFA] were lower in horses that do aerobic exercise regularly ${ }^{(12)}$; probably because of the increase in LPS activity and more mobilization of NEFA in exercised animals compared to maintenance horses. During aerobic exercise, [NEFA] increase after the exercise test ${ }^{(1)}$, and previous aerobic exercise may promote a much early increase in [NEFA] in exercised horses ${ }^{(17)}$, which is important to horses that do sports of many challenges in short periods, like marcha gaited championships and helpers in "vaquejada". In four-beat gaited horses submitted to 30 min of marcha gait competition, the [NEFA] ranged from $\sim 110 \mathrm{mmol} / \mathrm{mL}$ in fasting pre-test, to $\sim 880$ $\mathrm{mmol} / \mathrm{mL}$ after 15 minutes; then it returned to $\sim 270 \mathrm{mmol} / \mathrm{mL}$ after 120 minutes after the end of the gait competition ${ }^{(18)}$. In contrast, in well trained Thoroughbreds supplemented with fat or in the control group, the [NEFA] after overnight fasting were $\sim 300 \mathrm{mmol} / \mathrm{mL}$ and $\sim 200 \mathrm{mmol} / \mathrm{mL}$, respectively, and during recovery, the [NEFA] was higher in the supplemented group $(\sim 300 \mathrm{mmol} / \mathrm{mL})$ than in the control group ( 220 $\mathrm{mmol} / \mathrm{mL})^{(19)}$, showing different adaptation in these groups. These results, combined, demonstrated that there was an increase in the [NEFA] in athletic horses during and after exercise competitions, contributing to their performance and recovery, mainly in horses that do aerobic exercise, confirming the importance of the fat supplementation for the glycogen sparing in athletic horses, like was shown in other 
equine disciples ${ }^{(6,8,17)}$.

Glycerol is another important product of the lipid metabolism, where it represents a biomarker of the breakdown of the triglycerides by the lipase. The glycerol concentration increased significantly during the supplementation in the MT-g and had some relation to the increase in [NEFA], which was not observed in the GT-g. In healthy horses, the variation in the glycerol concentration is between 25 to $45 \mathrm{mg} / \mathrm{L}$, but it is $\sim 92 \mathrm{mg} / \mathrm{L}$ in colic horses $(17,20)$. In the present study, blood samples were collected after 12 hours of fasting in both groups, and after 24 hours of the last exercise training in GT-g and represent the actual utilization and storages of this biomarker in the animal body.

Variation in glycerol concentration has some relation with the exercise level and how horses do recovery of their muscles' fat storages. Some researchers found that during aerobic exercise competition (gait), the glycerol content increased from $\sim 49 \mathrm{mg} / \mathrm{L}$, in the pre-test, to $\sim 368 \mathrm{mg} / \mathrm{L}$ after 15 minutes of gait, and decreased to $\sim 83 \mathrm{mg} / \mathrm{L}$ after 120 minutes $^{(18)}$. It was different from the behavior observed in intense exercise that glycerol ranged from $\sim 30 \mathrm{mg} / \mathrm{L}$, in rest, to $\sim 45 \mathrm{mg} / \mathrm{L}$ after exercising (gallop) and it was $\sim 100 \mathrm{mg} / \mathrm{L}$ during recovery ${ }^{(19)}$. Duren et al. ${ }^{(21)}$ also showed that during the gallop recovery, horses that were fed 3 hours before exercise showed glycerol content significantly lower ( $~ 80 \mathrm{mg} / \mathrm{L})$ in comparison to those that made exercise after fasting or were fed 8 hours before $(\sim 100 \mathrm{mg} / \mathrm{L})$. These changes in glycerol production has association with degradation of triglycerides and NEFA's production by lipase in different species. This fact is an important find for athletic horses, mainly for those that do aerobic exercises such as endurance and gait tests, and may have access to food during their competition, contributing to restore muscle's fat storages.

The lipoprotein lipase (LPS) is an important enzyme associated with blood lipid regulation in horses and other species, acting in vascular endothelium and regulating the uptake of triglycerides in skeletal muscle and adipose tissues. In the present study, the LPS activity showed an inverse pattern to the NEFA content, with a significant reduction in its concentration after 8 weeks of supplementation in the MT-g and GTg. These results are opposite to those found by other researchers who showed an increase in LPS activity after supplementation with concentrates rich in $\mathrm{fat}^{(3,21)}$. The LPS activity, in the pre-test in both groups was between 196 to $240 \mathrm{U} / \mathrm{L}$, and after 8 weeks of supplementation, it ranged from 130 to $160 \mathrm{U} / \mathrm{L}$, demonstrating an increase in NEFA with the oil supplementation, but no increase in cholesterol (total, LDL and $\mathrm{HDL}$ ) concentrations and no decrease in triglyceride concentration. In addition, the results presented herein for total cholesterol, LDL, HDL, and triglyceride values for the MT-g and GT-g were similar to normal values in adult horses ${ }^{(15)}$. It is worth mentioning that in this study we did not measure VLDL and chylomicrons.

At the literature, the normal range for LPS activity in horse varies from 23 to $87 \mathrm{U} / \mathrm{L}^{(15)}$, which is lower than the values observed in the present study for both groups in the pre-test and during the whole supplementation program. In horse plasma, the LPS activity was about $50 \%$ higher after fat feeding when compared with carbohydrate 
feeding ${ }^{(3)}$, helping the whole fat metabolism in this specie. Horses that do moderate exercise and are supplemented with fish oil had lower triglyceride and higher LPS activity, and this process was probably related to the VLDL oxidation and reduction of triglyceride in the blood ${ }^{(11)}$. Apparently, a large increase in the availability of NEFA after 8 weeks of supplementation, produced negative effects on LPS activity in the MT-g and GT-g, which were expected because the access to metabolized fat from the supplementation reduce the utilization of the LPS. In addition, we did not determine the composition of the blood NEFA and other lipids, and this variation in blood fatty acids composition, after oil supplementation, may be associated with the decrease in LPS activity in our experimental horses.

There are few studies about the effects of fat supplementation on blood minerals in horses. Supplementation with fat apparently did not alter the electrolyte balance ${ }^{(22)}$, but when horses receive a treatment with omeprazole, which modify stomach $\mathrm{pH}$ and fat absorption in animals, produced a significant increase in total cholesterol and a decrease in plasma triglycerides, $\mathrm{P}$, and $\mathrm{Mg}$ in comparison with the control group ${ }^{(23)}$. Zeyner et al.(24) also showed that showjumping and dressage horses under high-fat supplementation ( $\sim 10 \%$ dry matter) during 28 days, had a decrease in $\mathrm{Ca}, \mathrm{P}$, and $\mathrm{Mg}$ blood concentration, in comparison with horses that received between 2 to $8 \%$ fat in dry matter. There is no clear explanation about the causes of these changes, but the increase in fat amount inside the stomach causes a reduction in the food transit time during digestion and may affect the absorption of some minerals. Finally, a significant reduction in P concentration in the MT-g, and in Ca in the GT-g, and an increase in Cl in both groups were not clinically relevant in short period ( 8 weeks) since these ranges were similar to normal values in adult horses ${ }^{(15)}$, but they need to be better evaluated in animals that received chronic supplementation with fat, which is common in horses that do aerobic exercise, like marcha gait challenges and endurances.

\section{Conclusion}

Supplementation with a combination of polyunsaturated oils increased NEFA concentration and reduced LPS activity in both groups, unlike the concentrations of the other biomarkers that showed different variations between groups, indicating that both NEFA and LPS the changes in their concentrations during supplementation may be more sensitive and more indicated for these types of evaluation.In addition, some blood mineral concentrations reduced significantly in both groups of horses, and thus, they need to be evaluated in horses under chronic oil supplementation.

\section{Acknowledgements}

The Cascatinha Horse Farm and Training Center (Camaragibe-PE, Brazil) and the Department of Animal Sciences (UFRPE) (Recife-PE, Brazil) for providing their animal and personal in both farms. 


\section{Funding}

They also thank the IntegralMix Animal Nutrition (Fortaleza-CE, Brazil) for providing financial support. Also, CAPES (AIADS) and CNPQ (SKMM) for student scholarships.

\section{Ethical Approval:}

All techniques used in this study were approved by the local animal care committee (UFRPE/CEUA \# 23082.007851/2007).

\section{Declaration of interest:}

The authors declare that there is no conflict of interest.

\section{References}

1. Piccione G, Assenza A, Borruso M, Fazio F, Caola G. Daily pattern of some fatty acids in the athletic horse. J Anim Physiol Anim Nutr (Berl).2008; 93:7-4.

2. Vervuert I, Klein S, Coenen M. Short-term effects of a moderate fish oil or soybean oil supplementation on postprandial glucose and insulin responses in healthy horses. Vet J. 2010; 184:162-166.

3. Schmidt O, Deegen E, Fuhrmann H, Dühlmeier R, Sallmann HP. Effects of Fat Feeding and Energy Level on Plasma Metabolites and Hormones in Shetland Ponies. J Vet Med Ser A Physiol Pathol Clin Med.2001;48:39-49.

4. Brunner J, Liesegang A, Weiss S, Wichert B. Feeding practice and influence on selected blood parameters in show jumping horses competing in Switzerland. J Anim Physiol Anim Nutr (Berl). 2015;99:684-691.

5. De Moffarts B, Portier K, Kirschvink N, Coudert J, Fellmann N, van Erck E, et al. Effects of exercise and oral antioxidant supplementation enriched in ( $\mathrm{n}-3)$ fatty acids on blood oxidant markers and erythrocyte membrane fluidity in horses. Vet J. 2007;174:113-121.

6. Bergero D, Assenza A, Caola G. Contribution to our knowledge of the physiology and metabolism of endurance horses. Livest. Prod. Sci. 2005;92:167-176.

7. Jansen WL, van der Kuilen J, Geelen SN, Beynen AC. The effect of replacing nonstructural carbohydrates with soybean oil on the digestibility of fibre in trotting horses. Equine Vet J. 2000;32:27-30.

8. Dunnett CE, Marlin DJ, Harris RC. Effect of dietary lipid on response to exercise: relationship to metabolic adaptation. Equine Vet J. 2002;34:75-90.

9. Orme CE, Harris RC, Marlin DJ, Hurley J. Metabolic adaptation to fat-supplemented diet by the thoroughbred horse. Br J Nutr. 1997;78:443-458.

10. Hallebeek JM, Beynen AC. The plasma level of triacylglycerols in horses fed high-fat diets containing either soybean oil or palm oil. J Anim Physiol Anim Nutr (Berl). 2002;86:111-116.

11. O'Connor $\mathrm{Cl}$, Lawrence LM, Hayes SH. Dietary fish oil supplementation affects serum fatty acid concentrations in horses. J Anim Sci. 2007;85:2183-2189.

12. Pleasant RS, Suagee JK, Thatcher CD, Elvinger F, Geor RJ. Adiposity, plasma insulin, leptin, lipids, and oxidative stress in mature light breed horses. J Vet Intern Med. 2013;c27:c576-582.

13. Harris P a, Pagan JD, Crandell KG, Davidson N. Effect of feeding thoroughbred horses a high unsaturated 
or saturated vegetable oil supplemented diet for 6 months following a 10 month fat acclimation. Equine Vet J Suppl. 1999;c30:c468-474.

14. Gomaa N, Koeller G, Schusser GF. Triglycerides, free fatty acids and total bilirubin in horses with left ventral colon impaction. Pferdeheilkunde.2009; c25:c137-140.

15. Perry BW. Clinical Pathology references data. In: Robinson NE, Sprayberry KA, editors. Current Therapy in Equine Medicine(Philadelphia, Saunders).2009; p. 956-998.

16. Watson TD, Burns L, Love S, Packard CJ, Shepherd J. Plasma lipids, lipoproteins and post-heparin lipases in ponies with hyperlipaemia. Equine Vet J. 1992;c24:c341-346.

17. Orme CE, Harris RC, Marlin DJ. Effect of elevated plasma FFA on fat utilization during low intensity exercise. Equine Vet J. 1995;c18:c199-204.

18. Ferreira LMC, Melo SKM, Diniz AIA, Vaz SG, Abreu JMG, Manso HECCC et al. Aerobic exercise produces changes in plasma II- 6 but not IL-1b in four-beat gaited horses. Comparative Exercise Physiology. 2015;11:c159-165.

19. Duren SE, Pagan JD, Harris PA, Crandell KG. Time of feeding and fat supplementation affect plasma concentrations of insulin and metabolites during exercise. Equine Vet J Suppl. 1999;30:479-484.

20. Edner AH, Nyman GC, Essén-Gustavsson B. Metabolism before, during and after anaesthesia in colic and healthy horses. Acta Vet Scand. 2007;49:1-16.

21. Marchello EV, Schurg WA, Marchello JA, Cuneo SP. Changes in lipoprotein composition in horses fed a fat-supplemented diet. J Equine Vet Sci. 2000;20:453-458.

22. Hoyt JK, Potter GD, Greene LW, Vogelsang MM, Anderson JG. Electrolyte Balance in Exercising Horses Fed a Control and a Fat-Supplemented Diet. J Equine Vet Sci. 1995;15:429-435.

23. Mélo SKM, Santiago TA, Duarte T de L, Abreu JMG, Manso HECCC, Manso Filho HC. 2014. A ProtonPump Inhibitor Modifies the Concentration of Digestion Biomarkers in Healthy Horses. J Equine Vet Sci. 2014;34:1318-1323.

24. Zeyner A, Kirbach $\mathrm{H}$, Fürll M. Effects of substituting starch with fat on the acid-base and mineral status of female horses. Equine Vet J. 2002;34:85-91. 